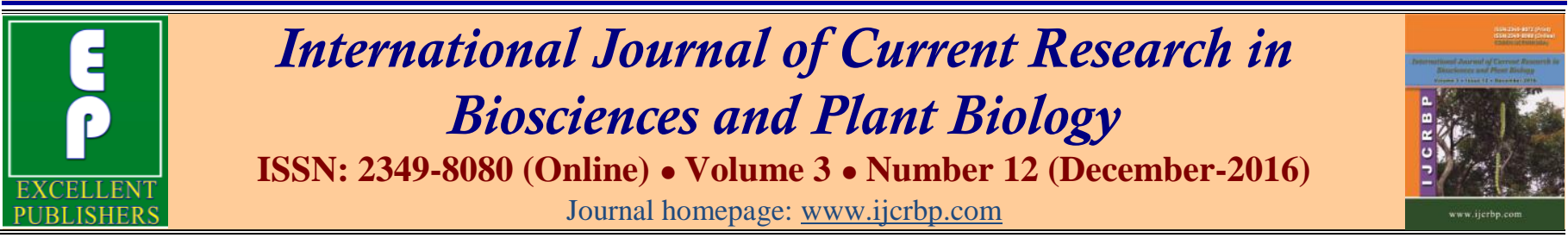

\title{
Resourceful and High Efficiency Agrobacterium Mediated Transformation of Maize (Zea mays L.) Using Coleoptilar Nodal Explants
}

\author{
P. Sreenu ${ }^{1,3}$, P. Sateesh Kumar'1, M. K. Reddy², D. Sailaja ${ }^{3}$ and G. Pavan Kumar ${ }^{1 *}$
}

${ }^{1}$ Nuziveedu Seeds Limited, Hyderabad, Hyderabad-501 401, Telangana, India

${ }^{2}$ International Centre for Genetic Engineering and Biotechnology (ICGEB), New Delhi-110 067, India

3Jawaharlal Nehru Technological University, Kukatpally, Hyderabad-50o o85, Telangana, India

*Corresponding author.

\section{Abstract}

Coleoptilar nodal explants, which are independent of season, were used to develop high efficiency transformation method in maize. Conditions which affect Agrobacterium-mediated genetic transformation have been standardized by using these explants on hygromycin selection regime. Hyper virulent Agrobacterium strain EHA105 containing gateway vector pMDC99 with Ascorbate - Glutathione pathway coding genes harboring with hygromycin phosphotransferase (hpt II) and bar as plant selectable marker genes was used. The survival frequency of calli at three different stages viz., at the end of I sub-culture on normal medium and II selection as well as on regeneration media supplemented with hygromycin were taken into consideration for the assessment of optimal conditions after checking with PCR. Of the different parameters used with different conditions, one day pre-conditioning of explants, 0.8 optical density of bacterial culture in plain MS liquid infection medium having $5.8 \mathrm{pH}$ along with $200 \mu \mathrm{M}$ acetosyrengone, 15 minutes infection time for the explants after treating with $0.1 \%$ Macerozyme, application of vacuum infiltration for 10 minutes, three days of co-cultivation period were found to be optimal for getting high frequency of transformation through Agrobacterium-mediated genetic transformation in maize. Transformation frequency of $3.25 \%$ was obtained on average with these optimal conditions, for which the explants were co-cultivated with these conditions and inoculated on callus induction medium having hygromycin at $10 \mathrm{mg} \mathrm{l}^{-1}$ for selection. The selected calli were transferred onto regeneration medium supplemented with BAP and Kinetin, at a concentration of $1 \mathrm{mg} \mathrm{l}^{-1}$ each for plantlet development. Putative transformants were screened by using hpt II gene specific primers and confirmed after performing southern analysis.

\section{Article Info}

Accepted: 17 November 2016

Available Online: 06 December 2016

\section{Ke y words}

Agrobacterium

Hygromycin

Maize

Transgenic plants

Abbreviations: 2, 4-D - 2, 4-Dichlorophenoxyacetic acid; hpt II - Hygromycin phosphotransferase; MS medium - Murashige and Skoog medium; YEP -Yeast Extract Peptone. 


\section{Introduction}

Gramineae, one of the largest monocotyledonous families which include more than 10,000 species including rice, maize and wheat. Next to rice and wheat maize is the staple food crop for human consumption, animal feed and bioethanol production as well as model plant for cereal research (Vega et al., 2001) throughout the world. Mainly this crop is affected by biotic as well as abiotic stresses which control the crop productivity. Hence, several approaches through conventional breeding were adopted to conquer these limitations. Even though these methods are fruitful, when considering the biotechnological methods, crop improvement programme through genetic engineering takes place in less time than conventional one. Particle bombardment method is expensive and has some limitations. Monocot cells were not susceptible for Agrobacterium and not the natural hosts of Agrobacterium tumefaciens (De Cleene and De Ley, 1976), but few hyper virulent strains were used for generating transgenic maize (De Cleene, 1985; Reyes et al., 2010). Recovery of fertile transgenic plants was first reported by Gordon-Kamm et al. (1990). This method was used to transform various maize target tissues, including immature zygotic embryos from inbred lines (Fromm et al., 1990; Gordon-Kamm et al., 1990; Frame et al., 2002; Ishida et al., 1996 and 2007).

Few critical parameters play the vital role in efficient recovery of transgenic maize through Agrobacterium mediated genetic transformation. Immature zygotic embryos and its derived calli were more suitable target explants for transformation in maize (Brettschneider et al., 1997; Songstad et al., 1996), but the availability of immature embryos throughout the year is difficult, laborious and seasonal dependant. Hence, alternative amenable seasonal independent explant from mature seed derived embryo (coleoptilar node) was chosen for this study. Zhang et al. (2002) and Huang and Wei (2004) used multiple shoots developed from the mature embryos. Cao et al. (2014) used multiple shoot developed from the coleoptilar node. The main objective of this study is to find out the suitable explant which is independent of season in giving reliable and consistent frequency of regeneration as well as transformation with Agrobacterium mediated genetic transformation on hygromycin selection regime. Some of the critical parameters viz., pre-conditioning of explants, density of bacterial population, strength and $\mathrm{pH}$ of the infection medium, acetosyrengone concentration, explant treatment with Macerozyme, vacuum application, infection time of explant with bacterial culture and cocultivation period which show significant effect on survival frequencies on selection media, regeneration and transformation frequencies were studied to establish the conditions for high throughput results.

\section{Materials and methods}

\section{Plant materials}

NM81A, a proprietary maize inbred line of Nuziveedu Seeds Limited, Hyderabad was used as a source material for the explants.

\section{Explant preparation}

Seeds were soaked in $2 \%$ Bavistin for one hour and subsequently washed with sterile distilled water for 3-4 times. Then the seeds were treated with $0.1 \% \mathrm{HgCl}_{2}$ and few drops of surfactant, Tween-20, for 15 minutes followed by thorough washing with sterile distilled water. Sterilized seeds were kept for germination on wet sterile cotton spread in the bottles. These bottles were kept in dark for three days at $27 \pm 1^{\circ} \mathrm{C}$, until the sprouts attain half inch length. Then the plumules were longitudinally sliced at coleoptile ring and coleoptilar nodal explants were separated from plumules and scutellae (Fig. 1A).

\section{Callus induction and regeneration}

MS medium (Murashige and Skoog, 1962) supplemented with 2, 4-D and Kinetin at a concentration of 5 and $1 \mathrm{mg}$ $\mathrm{I}^{-1}$ respectively was used for callus induction. MS medium with BAP and Kinetin, each at $1 \mathrm{mg} \mathrm{l}^{-1}$ concentration was used for regeneration and plain MS medium without any hormones for rooting.

\section{Agrobacterium strain and construct}

Agrobacterium hyper virulent strain, EHA105, was used with gateway vector pMDC99 containing AscorbateGlutathione pathway coding genes tailored in single vector under stress inducible promoter $r d 29$ driven by $T 7$ RNA polymerase for high expression of transgenes with hpt II and bar as plant selectable markers.

\section{Transformation}

\section{Selection of transformed callus}

Medium used for callus induction was supplemented with filter sterilized hygromycin at a concentration of 10 $\mathrm{mg}^{-1}$ and used for selection purpose. After first 
subculture, explants were transferred onto selection medium for further selection. After two subcultures on selection media, putative transformed calli (Hygromycin resistant) were transferred onto fresh regeneration medium for shoot regeneration (Fig. 1C and 1D).

\section{Plant regeneration and acclimatization}

Hygromycin selected calli were transferred onto regeneration medium (Murashige and Skoog, 1962) having BAP and Kinetin each at $1 \mathrm{mg} \mathrm{l}^{-1}$ and incubated in light for 15 days and regenerated shoots were transferred to plain MS medium for further plant elongation and rooting. Profusely rooted shoots were washed in running tap water and transferred into polythene disposable cups having a mixture of cocopeat, perlite and soil in a ratio of $1: 1: 1$ and covered with transparent polythene cover to maintain proper humidity. After one week, the plants were transferred into pots containing a mixture of soil, farmyard manure and sand in a ratio of 4:4:1 until maturation and seed setting (Fig. 1E).

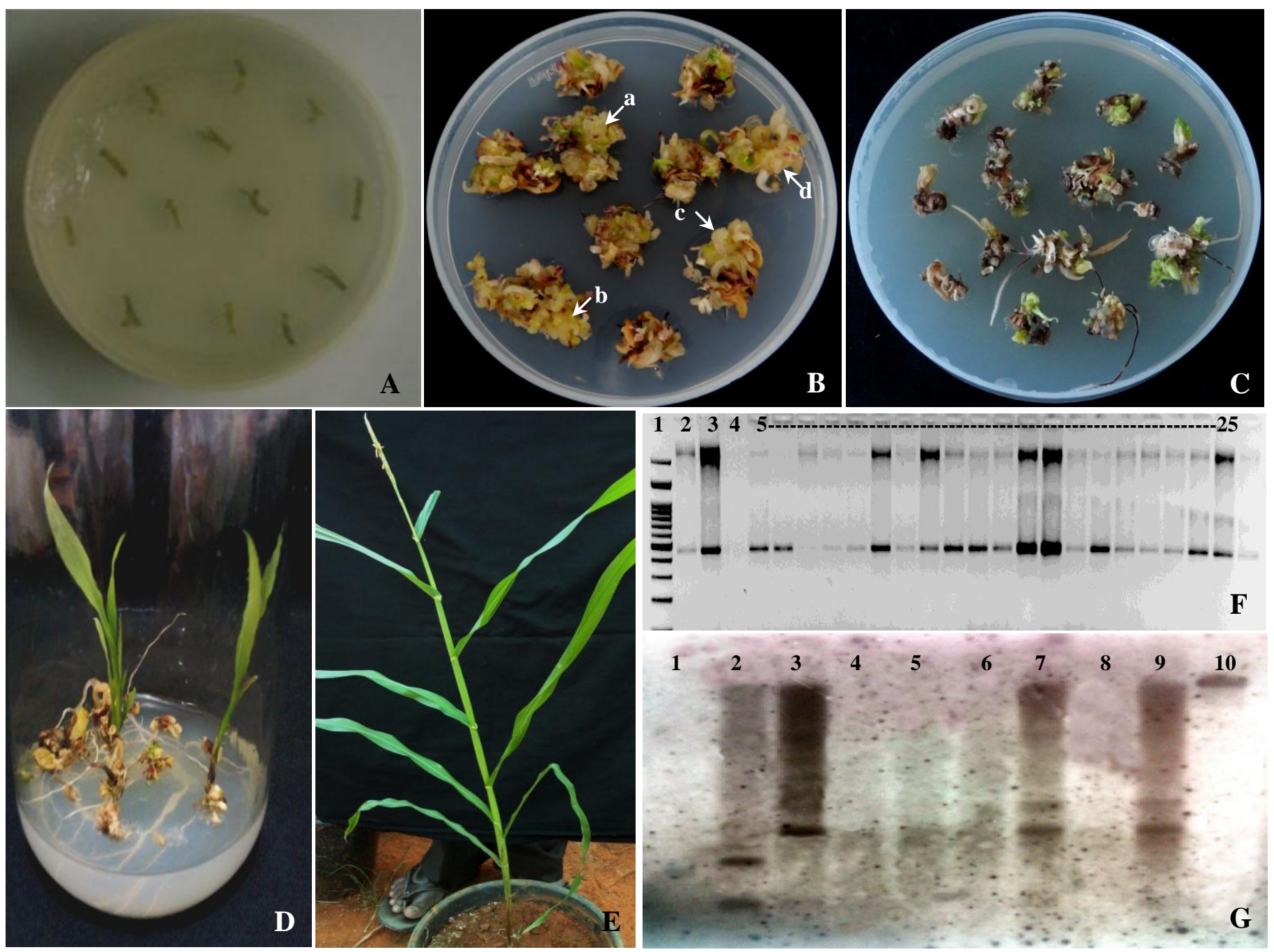

Fig. 1: Agrobacterium mediated genetic transformation in maize using coleoptilar nodal explants (A); showing callus proliferation from the explants $(\mathbf{B})$ with embryogenic $(\mathbf{a} \& \mathbf{b})$ and non-embryogenic calli (c \& $\mathbf{d})$; Callus proliferation on selection medium supplemented with hygromycin $(\mathbf{C})$; Regeneration and rooting of shoots (D); Hardened putative transgenic maize plant in polyhouse (E); Molecular screening of putative transgenic plants through PCR using hpt II primers resulted in 480bp amplicon (F, 5-25); 100bp ladder (1), plasmid DNAs (2\&3), control wild type genomic DNA (4) also seen on the gel; Integration of genes in transgenic plants were confirmed through southern blotting using hpt II probe (G) showing control wild type plant DNA (1), different putative transgenic lines (2-9) and undigested transgenic DNA (10) also seen on blot. 


\section{PCR analysis}

Genomic DNAs were extracted by C-TAB method (Doyle and Doyle, 1990) from both transformed as well as untransformed (control) plants. Putative transgenic plants which were selected through Hygromycin selection were subjected to PCR analysis using hpt II gene specific primers viz., Forward 5' CACAATCCCACTATCCTTCGC $3^{\prime}$ and Reverse 5' GCAGTTCGGTTTCAGGCAGGT 3' which result in 480bp amplicon (Fig. 1F). The amplified product was visualized on $1 \%$ Agarose gel.

\section{Southern blot analysis}

Gene integration and copy number was determined by using southern blot technique. Genomic DNA was isolated from both the PCR positive with hpt II gene and wild type control plants by C-TAB method (Doyle and Doyle, 1990). $10 \mu \mathrm{g}$ of genomic DNA of both PCR positive and wild type control plants was digested with Bam HI restriction enzyme (10units/ $\mu \mathrm{g}$ ) overnight at $37^{\circ} \mathrm{C}$ in water bath. Then the digested products were separated on $0.8 \%$ Agarose gel using $60 \mathrm{~V}$ current and the depurinated gel was transferred to positively charged Hyband- $\mathrm{N}^{+}$Nylon membrane (Amersham Biosciences, UK) by upward capillary method described by Sambrook and Russel (2001). The probe DNA containing 980bp was amplified in pMDC99 plasmid by using specific primers-

HPTPRF: 5' GCCTGAACTCACCGCGACG 3' and HPTPRR: 5' CAGCCATCGGTCCAGACG 3'

Then the UV cross linked Nylon membrane was probed with non-radioactive (Alkaphos) labeled $h p t$ II gene at $55^{\circ} \mathrm{C}$ in Hybridization oven with $60 \mathrm{rpm}$ for 15 hours and finally the membrane was washed with primarywash buffer followed by secondary-wash buffer. Detection reagent was applied to the membrane and finally exposed to X-ray film for $4 \mathrm{hrs}$. Then the film was developed in Kodak fixer and developer in dark for copy number enumeration. All the above procedures were followed as per kit instructions manual (Amersham Biosciences, UK).

\section{Statistical analysis}

Data obtained on the effects of various parameters on survival frequencies on hygromycin selection regime were subjected to statistical analysis by following Snedecor and Cochran (1968).

\section{Results and discussion}

Coleoptilar nodal explants were used for optimization of influencing parameters on recovery of hygromycin selected putative transgenic plants developed through Agrobacterium mediated genetic transformation. Isolated three day old explants were inoculated on MS medium (Murashige and Skoog, 1962) supplemented with 2, 4-D and Kinetin at a concentration of 5 and $1 \mathrm{mg}$ $1^{-1}$ respectively for callus induction (Fig. 1A). Cultures were incubated in dark and light for 15 and 30 days respectively at $27 \pm 1^{\circ} \mathrm{C}$ by sub-culturing onto to the same medium at an interval of two weeks (Fig. 1B). Embryogenic calli developed from these cultures were transferred onto MS medium fortified with BAP and Kinetin, each at $1 \mathrm{mg} \mathrm{l}^{-1}$ concentration for regeneration.

Elongated shoots were separated and transferred onto plain MS medium without any hormones for rooting. Profusely rooted shoots were acclimatized in polyhouse for further development and seed set. These cultures were served as controls for this study. Prior to transformation, a potential concentration of hygromycin for the selection of transformed calli was determined by culturing explants on medium containing various concentrations of hygromycin viz., 0, 3, 5, 10, 15 and 20 $\mathrm{mg} \mathrm{l}^{-1}$. Hygromycin, at a concentration $10 \mathrm{mg} \mathrm{l}^{-1}$, was observed as an effective one for coleoptilar nodal explants, where the browning and complete necroses of explants were observed. This concentration was adopted throughout this study for the selection of transformants. For evaluating the parameters under the different conditions, data was studied at three different stages viz., survival frequencies at the end of dark phase (sub-culture I) and at the end of each sub-culture on selection medium i.e., selection I and selection II (at the end of 15 days each) and also the regeneration frequency after transferring from the selection medium (Table 1). Pieces of calli from selection II medium and regenerated plant samples were checked with PCR for screening the putatives.

\section{Effect of pre-conditioning of explants}

Initially, embryogenic callus was subjected to cocultivation, where the callus masses turned brown and no positive results were observed. Hence, coleoptilar nodal explants were used for co-cultivation. Prior to cocultivation coleoptilar nodal explants were preconditioned for 24 and $48 \mathrm{hrs}$ on callus induction medium. Explants without pre-conditioning have also been maintained to evaluate the effect. Among the three 
conditions tested, 24 hrs pre-conditioning of the explants resulted in maximum survival frequency on hygromycin selection $(14.9 \%)$ as well as regeneration $(6.5 \%)$. Low survival frequencies were observed in other two conditions i.e., without pre-conditioning and $48 \mathrm{hrs}$ treatment (Table 1), due to neonate and cell rigidity. Similar results were observed in wheat (Wu et al., 2003) and maize (Takavar et al., 2010).

Table 1. Effect of different parameters with different variables on survival frequency obtained on normal, selection medium supplemented with hygromycin and regeneration medium of maize cultures after co-cultivating with Agrobacterium cultures.

\begin{tabular}{|c|c|c|c|c|c|}
\hline Parameter & Variable & Subculture* & Sel-I* & Sel-II* & $\begin{array}{l}\text { Regeneration } \\
\text { frequency* }\end{array}$ \\
\hline Pre-conditioning of the explants & $\begin{array}{l}0 \mathrm{hrs} \\
24 \mathrm{hrs} \\
48 \mathrm{hrs}\end{array}$ & $\begin{array}{l}39.24 \pm 7.51 \\
70.00 \pm 4.47 \\
43.75 \pm 6.43\end{array}$ & $\begin{array}{l}25.00 \pm 2.52 \\
37.00 \pm 5.51 \\
30.00 \pm 8.09\end{array}$ & $\begin{array}{l}10.6 \pm 1.53 \\
14.9 \pm 1.16 \\
9.10 \pm 2.00\end{array}$ & $\begin{array}{l}4.6 \pm 1.00 \\
6.5 \pm 1.16 \\
3.7 \pm 0.58\end{array}$ \\
\hline Optical Density of bacterial culture & $\begin{array}{l}0.6 \\
0.8 \\
1\end{array}$ & $\begin{array}{l}42.50 \pm 5.00 \\
73.34 \pm 1.59 \\
53.34 \pm 2.00\end{array}$ & $\begin{array}{l}37.5 \pm 3.52 \\
62.0 \pm 2.51 \\
42.67 \pm 7.64\end{array}$ & $\begin{array}{l}16.67 \pm 2.52 \\
30.00 \pm 6.03 \\
22.67 \pm 4.51\end{array}$ & $\begin{array}{l}6.9 \pm 1.53 \\
14.3 \pm 3.22 \\
11.7 \pm 1.16\end{array}$ \\
\hline Strength of the infection medium & $\begin{array}{l}\text { Half plain MS } \\
\text { Full plain MS } \\
\text { Osmo. Med. }\end{array}$ & $\begin{array}{l}83.34 \pm 6.63 \\
74.00 \pm 7.22 \\
70.00 \pm 1.56\end{array}$ & $\begin{array}{l}60.0 \pm 5.14 \\
48.0 \pm 6.81 \\
43.0 \pm 7.51\end{array}$ & $\begin{array}{l}30.00 \pm 3.00 \\
25.00 \pm 3.61 \\
20.00 \pm 5.04\end{array}$ & $\begin{array}{l}12.5 \pm 2.31 \\
12.7 \pm 2.31 \\
9.00 \pm 2.00\end{array}$ \\
\hline $\mathrm{pH}$ of the infection medium & $\begin{array}{l}5.2 \\
5.4 \\
5.8\end{array}$ & $\begin{array}{l}45.46 \pm 4.17 \\
66.67 \pm 1.07 \\
76.93 \pm 6.08\end{array}$ & $\begin{array}{l}18.19 \pm 3.61 \\
53.34 \pm 1.08 \\
57.70 \pm 7.22\end{array}$ & $\begin{array}{l}12.73 \pm 1.00 \\
26.67 \pm 7.51 \\
30.77 \pm 7.51\end{array}$ & $\begin{array}{l}6.20 \pm 0.58 \\
9.40 \pm 4.00 \\
12.8 \pm 2.89\end{array}$ \\
\hline Acetosyrengone concentration & $\begin{array}{l}0 \mu \mathrm{M} \\
100 \mu \mathrm{M} \\
200 \mu \mathrm{M}\end{array}$ & $\begin{array}{l}41.67 \pm 6.81 \\
80.00 \pm 5.00 \\
78.58 \pm 1.15\end{array}$ & $\begin{array}{l}33.34 \pm 4.05 \\
60.00 \pm 2.00 \\
60.72 \pm 8.74\end{array}$ & $\begin{array}{l}15.00 \pm 1.16 \\
32.00 \pm 3.52 \\
35.72 \pm 3.06\end{array}$ & $\begin{array}{l}7.00 \pm 0.58 \\
17.6 \pm 1.53 \\
18.7 \pm 1.16\end{array}$ \\
\hline Macerozyme treatment & $\begin{array}{l}0.1 \% \\
0.2 \% \\
0.5 \%\end{array}$ & $\begin{array}{l}63.64 \pm 2.09 \\
60.00 \pm 3.06 \\
26.12 \pm 3.61\end{array}$ & $\begin{array}{l}45.46 \pm 5.00 \\
35.00 \pm 3.06 \\
21.12 \pm 2.00\end{array}$ & $\begin{array}{l}23.00 \pm 5.04 \\
16.00 \pm 2.09 \\
12.00 \pm 2.00\end{array}$ & $\begin{array}{l}12.0 \pm 2.52 \\
8.70 \pm 1.16 \\
6.10 \pm 1.53\end{array}$ \\
\hline Vacuum infiltration & $\begin{array}{l}0 \text { min. } \\
10 \mathrm{~min} . \\
15 \mathrm{~min} .\end{array}$ & $\begin{array}{l}54.74 \pm 4.17 \\
64.29 \pm 7.56 \\
60.29 \pm 3.66\end{array}$ & $\begin{array}{l}37.9 \pm 6.25 \\
46.43 \pm 1.79 \\
42.25 \pm 1.66\end{array}$ & $\begin{array}{l}14.74 \pm 1.00 \\
25.00 \pm 1.94 \\
19.56 \pm 4.51\end{array}$ & $\begin{array}{l}9.20 \pm 1.00 \\
12.5 \pm 5.69 \\
12.2 \pm 3.22\end{array}$ \\
\hline Infection time & $\begin{array}{l}10 \text { min. } \\
15 \text { min. } \\
30 \text { min. }\end{array}$ & $\begin{array}{l}45.46 \pm 1.00 \\
73.08 \pm 5.69 \\
66.67 \pm 3.22\end{array}$ & $\begin{array}{l}30.00 \pm 5.00 \\
46.16 \pm 4.16 \\
30.00 \pm 5.14\end{array}$ & $\begin{array}{l}13.64 \pm 4.17 \\
19.24 \pm 3.06 \\
16.00 \pm 3.06\end{array}$ & $\begin{array}{l}8.0 \pm 2.52 \\
8.9 \pm 2.00 \\
7.6 \pm 1.16\end{array}$ \\
\hline Co- cultivation period & $\begin{array}{l}2 \text { days } \\
3 \text { days } \\
4 \text { days }\end{array}$ & $\begin{array}{l}54.55 \pm 2.65 \\
71.43 \pm 2.17 \\
58.34 \pm 2.00\end{array}$ & $\begin{array}{l}31.82 \pm 5.14 \\
50.00 \pm 5.00 \\
25.00 \pm 2.52\end{array}$ & $\begin{array}{l}21.82 \pm 1.00 \\
34.29 \pm 6.56 \\
20.84 \pm 1.00\end{array}$ & $\begin{array}{l}13.2 \pm 2.09 \\
21.5 \pm 2.09 \\
11.7 \pm 2.65\end{array}$ \\
\hline
\end{tabular}

*Average value \pm Std. Dev.

\section{Effect of bacterial population (OD at 580nm)}

Bacterial cell density in the culture, which is measures as optical density of the culture at $580 \mathrm{~nm}$, influences the transformation frequency, hence agrobacterial cells cultured overnight in liquid YEP medium containing 50 $\mathrm{mg}^{-1}$ kanamycin along with $25 \mathrm{mg} \mathrm{l}^{-1}$ each of rifampicin and streptomycin at $28^{\circ} \mathrm{C}$ in a shaker at $180 \mathrm{rpm}$ were harvested at deferent timing after attaining the OD of 0.6 , 0.8 and 1.0 by spinning at $6000 \mathrm{rpm}$ at $4^{\circ} \mathrm{C}$ for 20 minutes, then these cultures were used for co-cultivation.
Explants co-cultivated with Agrobacterium cells harvested from the culture with 0.8 optical densities (at $580 \mathrm{~nm}$ ) resulted in maximum survival frequency in hygromycin selection (30\%) and regeneration (14.3\%) than the other ODs tried (Table 1). Minimum frequency of survival with $16.67 \%$ and regeneration with $6.9 \%$ were observed at 0.6 OD. At this 0.8 O.D., Agrobacterial cells at exponential phase of their growth were very effective for resulting high frequency of transformation (Yadav et al., 2012). Survival frequency on hygromycin selection medium was declined with increase in bacterial 
cell density at 1.0 OD. Similar results were observed in sunflower (Sujatha et al., 2012) and Populus (Han et al., 2013).

\section{Effect of infection medium}

Agrobacterium cells were suspended in various liquid infection media viz., plain half MS medium, plain MS medium and osmoticum medium (MS medium with $3.6 \%$ Glucose and 6\% Sucrose) for the assessment of selection frequency. Among the media used, both plain MS as well as half MS media showed more or less equal regeneration frequencies ( $12.7 \%$ and $12.5 \%$ respectively) though the survival frequencies were 25 and $30 \%$ respectively (Table -1 ) with low tissue browning than in osmoticum medium. Browning of the explants was observed upon usage the osmoticum medium and explants were dead in further subcultures with only $9 \%$ of regeneration frequency. In contrary to this, other workers reported the enhanced transformation frequency by using osmolytes in tree plants (Li et al., 2007), rye grass (Patel et al., 2013) and in sorghum (Wu et al., 2014).

\section{pH of the infection medium}

Different $\mathrm{pH}$ values of liquid infection medium at 5.2, 5.4 and 5.8 were tried to assess the hygromycin selection frequency. Infection medium with $5.8 \mathrm{pH}$ showed maximum frequencies of selection as well as regeneration (30.77\% and $12.8 \%$ respectively). In other infection media with low acidic $\mathrm{pH}$ of 5.2 and 5.4 resulted in low survival frequencies of $6.2 \%$ and $9.4 \%$ respectively for regeneration and $12.73 \%$ and $26.67 \%$ (Table 1) on selection media where the explants turned brown after co-cultivation. In present study, a negative correlation of survival frequencies was observed with increase in hydrogen ion concentration in the media (low $\mathrm{pH})$ on both selection as well regeneration media. In other studies, it was suggested that acidic $\mathrm{pH}$ of the infection medium enhanced the transformation frequency (De La Riva et al., 1998; Saini and Jaiwal., 2007).

\section{Effect of acetosyrengone concentration}

Two concentrations viz., 100 and $200 \mu \mathrm{M}$ of acetosyrengone were used for enhancing the survival frequency of calli on hygromycin. Of which, $200 \mu \mathrm{M}$ showed maximum selection and regeneration frequencies (35.72\% and 18.7\%); minimum frequencies were observed at $100 \mu \mathrm{M}$ concentration (32 and 17.6\%) as well as in absence of acetosyrengone (15 and7\%) (Table 1).
Transformation studies in other crop plants also indicated that acetosyrengone at an appropriate concentration enhances efficiency of transformation frequency as in Catharanthus (Srivastava et al., 2009) and sunflower (Sujatha et al., 2012). In Populus, presence of acetosyrengone did not show any enhancement in transformation frequency (Han et al., 2013).

\section{Effect of macerozyme treatment}

Explants were treated with different concentrations (0.1, 0.2 and $0.5 \%$ ) of macerozyme for 5 minutes before going to infect with bacteria. After this treatment, explants were immersed in liquid infection medium containing agrobacterial cells. Negative effect of macerozyme pretreatment was observed on explant health after cocultivation. In higher concentrations of macerozyme (at 0.2 and $0.5 \%$ ) explants were putrefied and hygromycin selection frequency was declined $(8.7 \%$ and $6.1 \%)$ when compared with lower concentration of macerozyme $(0.1 \%)$ which resulted in $12 \%$ of regeneration and $23 \%$ of selection frequencies (Table 1). In present study, no significant difference was observed in regeneration frequency with or without macerozyme treatment; whereas in sunflower Weber et al. (2003) reported enhanced transformation frequency by using macerating agents.

\section{Vacuum infiltration for the explants}

Giving suction pressure while infecting the explants with bacterial culture enhances and or facilitate bacteria to enter the host cells easily which in turn shows its effect on subsequent selection as well as regeneration frequencies. By considering this, explants were infected with Agrobacterium culture by applying vacuum at two different timings (10 and $15 \mathrm{~min}$.) at a pressure of $75 \mathrm{Hg}$. In contrary to our consideration, application of vacuum both for 10 and 15 minutes showed more or less equal regeneration frequencies and more than without vacuum application $12.5 \%, 12.2 \%$ and $9.2 \%$ respectively (Table 1). No significant enhancement in survival frequency was observed by the application of vacuum in wheat (Cheng et al., 1997). Cao et al. (2014) applied vacuum for 30 minutes in maize. In contrary to this, present study revealed that the application of vacuum for 10 or 15 minutes enhanced the survival frequency on hygromycin selection medium. In particular, 10 minutes duration is suitable than 15 minutes, where the significant enhancement has been noticed not only in survival frequency on selection medium, but also the regeneration frequency too. 


\section{Effect of infection time}

Explants were infected with Agrobacterium culture with different time durations viz., 10, 15 and 30 minutes. Because it would cause either damage to the tissue when time exceeds or failure due to poor intrusion of bacterial cells into the explant as the exposure time is insufficient. Of the infection durations given in this study, 15 minutes exposure time resulted in maximum frequencies of selection $(19.24 \%)$ as well as regeneration $(8.9 \%)$ than any other durations tried. Long exposures of explants to Agrobacterium cells results in over growth of bacteria around the explants and browning or decay of cultures in further subcultures which causes decline in survival frequencies on selection medium. In 10 and 30 minutes infection duration 13.64 and $16 \%$ of survival frequencies and 8 and $7.6 \%$ of regeneration frequencies were observed respectively (Table 1). Similar trend of results were reported in wheat by Wu et al. (2003).

\section{Co-cultivation period}

After infection, the explants were transferred to cocultivation medium supplemented with $200 \mu \mathrm{M}$ acetosyrengone for different durations (Two, Three and Four days). Among them, co-cultivation for three days resulted in maximum survival frequency on hygromycin selection medium than the others tried (34.29\%) and also $21.5 \%$ of regeneration frequency was observed (Table 1 ). In this study, co-cultivation for four days showed over growth of the bacteria and putrefaction of explants were observed even after giving cefotaxime $\left(250 \mathrm{mg} \mathrm{l}^{-1}\right)$ washing to the explants. Recurrent over growth of bacteria was observed in further subcultures also. Similar results were reported by $\mathrm{Li}$ et al. (2004); Uranbey et al. (2005) and Sujatha et al. (2012). Hygromycin selection frequencies were declined in two and four day co-cultivation with $21.82 \%$ and $20.84 \%$ respectively.

Coleoptilar explants were inoculated in large number with many replicates to assess the transformation frequency by using all optimal conditions selected. An average of $3.25 \%$ transformation frequency was obtained and the data was given in Table 2. The putatives are screened by PCR (Fig. 1F) and the positive samples were subjected to southern analysis by using hpt probe, which revealed the presence of 1-3 inserts (Fig. 1G).

Table 2. Transformation frequency of maize obtained through Agrobacterium mediated transformation selected on hygromycin regime and subsequent molecular screening of putative transgenics through PCR using hpt II primers.

\begin{tabular}{llllll}
\hline $\begin{array}{l}\text { No. of explants } \\
\text { Co-cultivated }\end{array}$ & $\begin{array}{l}\text { Survival frequency } \\
\text { in Selection - I }\end{array}$ & $\begin{array}{l}\text { Survival } \\
\text { frequency in } \\
\text { Selection - II }\end{array}$ & $\begin{array}{l}\text { Frequency of } \\
\text { regeneration }\end{array}$ & $\begin{array}{l}\text { PCR +ves for } \\
\text { hpt II }\end{array}$ & $\begin{array}{l}\text { Transformation } \\
\text { frequency (\%) }\end{array}$ \\
\hline 1045 & $61.81(646)$ & $34.25(358)$ & $22.34(80)$ & 34 & 3.25 \\
\hline
\end{tabular}

*Total number of calli tested is given in parentheses.

Recovery of fertile transgenic plants through Agrobacterium mediated genetic transformation depends on several crucial parameters. Thorough optimizing and tuning those parameters with different genotypes are necessary for getting high frequencies of transformation (Cao et al., 2014), where different genotypes were used by considering the different parameters and achieved $2 \%$ transformation frequency in maize using multiple shoots developed from the coleoptilar nodal explant. In contrary to this, in present study transformation studies have been done by using callus cultures developed from the same explant and frequencies were assessed by using hygromycin selection frequency (Nyaboga et al., 2014). In the present study, it was concluded that the parameters viz., one day pre-conditioning of explants, 0.8 optical density of bacterial culture in plain MS liquid infection medium having $5.8 \mathrm{pH}$ along with $200 \mu \mathrm{M}$ acetosyrengone, 15 minutes infection time for the explants after treating with $0.1 \%$ Macerozyme, application of vacuum infiltration for 10 minutes, three days of co-cultivation period, play a vital role in maize transgenic development from coleoptilar nodal explant. By using above optimized parameters an average transformation frequency of $3.25 \%$ was achieved. Comparatively, explants derived from the mature embryos (Cao et al., 2014; Huang and Wei, 2005; Zhong et al., 1996) yielded less frequencies of transformation than the immature embryos (Ishida et al., 1996). All these conditions of different parameters would help us in developing a congenial high throughput method of Agrobacterium mediated genetic transformation in maize. Similar studies were done in Rice (Ignacimuthu and Raveendar, 2011; Sahoo and Tuteja, 2012) and Yam (Nyaboga et al., 2014). This study will help in maize genetic engineering for 
agronomically demand traits into recalcitrant maize genotypes. By using these parameters fertile putative transgenic maize plants were produced.

\section{Conflict of interest statement}

Authors declare that they have no conflict of interest.

\section{Acknowledgement}

This work was financially supported by SBIRI (Small Business Innovation Research Initiative), a scheme of DBT (Department of Biotechnology), Ministry of Science \& Technology, Government of India, India (BCIL/SBIRI/2009 - 2061). The authors are thankful for the support.

\section{References}

Brettschneider, R., Becker, D., Lorz, H., 1997. Efficient transformation of scutellar tissue of immature maize embryos. Theor. Appl. Genet. 94(6-7), 737-748.

Cao, S.L., Masilamany, P., Li, W.B., Pauls, K.P., 2014. Agrobacterium tumefaciens-mediated transformation of corn (Zea mays L.) multiple shoots. Biotechnol. Biotechnol. Equip. 28(2), 208-216.

Cheng, M., Fry, J.E., Pang, S., Zhou, H., Hironaka, C.M., Duncan, D.R., Conner, T.W., Wan, Y., 1997. Genetic transformation of wheat mediated by Agrobacterium tumefaciens. Plant Physiol. 115(3), 971-980.

De Cleene, M., 1985. The susceptibility of monocotyledons to Agrobacterium tumefaciens. J. Phytopathol. 113(1), 8189.

De Cleene, M., De Ley, J., 1976. The host range of crown gall. Bot. Rev. 42(4), 389-466.

De La Riva, G.A., Gonzalez-Cabrera, J., Vazquez-Padron, R., Ayra-Pardo, C., 1998. Agrobacterium tumefaciens: A natural tool for plant transformation. Electr. J. Biotechnol. 1(3), 24-25.

Doyle, J.J., Doyle, J.L., 1990. Isolation of plant DNA from fresh tissue. Focus. 12(1), 13-15.

Frame, B.R., Shou, H., Chikwamba, R.K., Zhang, Z., Xiang, C., Fonger, T.M., Pegg, S.E.K., Li, B., Nettleton, D.S., Pei, D., Wang, K., 2002. Agrobacterium tumefaciensmediated transformation of maize embryos using a standard binary vector system. Plant Physiol. 129(1), 1322.

Fromm, M.E., Morrish, F., Armstrong, C., Williams, R., Thomas, J., Klein, T.M., 1990. Inheritance and expression of chimeric genes in the progeny of transgenic maize plants. Nature Biotechnol. 8(9), 833-839.

Gordon-Kamm, W.J., Spencer, T.M., Mangano, M.L., Adams, T.R., Daines, R.J., Start, W.G., O'Brien, J.V., Chambers, S.A., Adams, W.R., Willetts, N.G., Rice, T.B., Mackey, C.J., Krueger, R.W., Kausch, A.P., Lemaux, P.G., 1990.
Transformation of maize cells and regeneration of fertile transgenic plants. Plant Cell. 2(7), 603-618.

Han, X., Ma, S., Kong, X., Takano, T., Liu, S., 2013. Efficient Agrobacterium-mediated transformation of hybrid poplar Populus davidiana Dodex Populus bollena Lauche. Int. J. Mol. Sci. 14(2), 2515-2528.

Huang, X., Wei, Z., 2005. Successful Agrobacterium-mediated genetic transformation of maize elite inbred lines. Plant Cell Tiss. Organ Cult. 83(2), 187-200.

Huang, X.Q., Wei, Z.M., 2004. High-frequency plant regeneration through callus initiation from mature embryos of maize (Zea mays L.). Plant Cell Rep. 22(11), 793-800

Ignacimuthu, S., Raveendar, S., 2011. Agrobacterium mediated transformation of indica rice (Oryza sativa L.) for insect resistance. Euphytica. 179(2), 277-286.

Ishida, Y., Hiei, Y., Komari, T., 2007. Agrobacteriummediated transformation of maize. Nature Protoc. 2(7), 1614-1621.

Ishida, Y., Saito, H., Ohta, S., Hiei, Y., Komari, T., Kumashiro, T., 1996. High efficiency transformation of maize (Zea mays L.) mediated by Agrobacterium tumefaciens. Nature Biotechnol. 14(6), 745-750.

Li, H.Y., Zhu, Y.M., Chen, Q., Conner, R.L., Ding, X.D., Li, J., Zhang, B.B., 2004. Production of transgenic soybean plants with two anti-fungal protein genes via Agrobacterium and particle bombardment. Biol. Plant. 48(3), 367-374.

Li, Z.N., Fang, F., Liu, G.F., Bao, M.Z., 2007. Stable Agrobacterium-mediated genetic transformation of London plane tree (Platanus acerifolia Wild.). Plant Cell Rep. 26(5), 641-650.

Murashige, T., Skoog, F., 1962. A revised medium for rapid growth and bio assays with tobacco tissue cultures. Physiol. Plant. 15(3), 473-497.

Nyaboga, E., Tripathi, J.N., Manoharan, R., Tripathi, L., 2014. Agrobacterium-mediated genetic transformation of yam (Dioscorea rotundata): an important tool for functional study of genes and crop improvement. Front. Plant Sci. 5, $1-14$.

Patel, M., Dewey, R.E., Qu, R., 2013. Enhancing Agrobacterium tumefaciens-mediated transformation efficiency of perennial ryegrass and rice using heat and high maltose treatments during bacterial infection. Plant Cell Tiss. Organ Cult. 114(1), 19-29.

Reyes, F.C., Sun, B., Guo, H., Gruis, D.F., Otegui, M.S., 2010. Agrobacterium tumefaciens-mediated transformation of maize endosperm as a tool to study endosperm cell biology. Plant Physiol. 153(2), 624-631.

Sahoo, R.K., Tuteja, N., 2012. Development of Agrobacterium-mediated transformation technology for mature seed-derived callus tissues of indica rice cultivar IR64. GM Crops Food. 3(2), 123-128.

Saini, R., Jaiwal, P.K., 2007. Agrobacterium tumefaciensmediated transformation of blackgram: An assessment of factors influencing the efficiency of uidA gene transfer. Biol. Plant. 51(1), 69-74. 
Sambrook, J., Russell, D.W., 2001. Molecular Cloning: A Laboratory Manual. $3^{\text {rd }}$ Edn. Cold Spring Harbor Laboratory Press, Cold Spring, NY.

Snedecor, G.W., Cochran, W.G.,1968. Statistical Methods. The Iowa State University Press, Ames, Iowa, USA. Oxford and IBH publishing Co. Pvt. Ltd., New Delhi.

Songstad, D.D., Armstrong, C.L., Petersen, W.L., Hairston, B., Hinchee, M.A.W., 1996. Production of transgenic maize plants and progeny by bombardment of Hi-II immature embryos. In Vitro Cell. Develop. Biol. Plant. 32(3), 179183.

Srivastava, T., Das, S., Sopory, S.K., Srivastava, P.S., 2009. A reliable protocol for transformation of Catharanthus roseus through Agrobacterium tumefaciens. Physiol. Mol. Biol. Plants. 15(1), 93-98.

Sujatha, M., Vijay, S., Vasavi, S., Reddy, P.V., Rao, S.C., 2012. Agrobacterium-mediated transformation of cotyledons of mature seeds of multiple genotypes of sunflower (Helianthus annuus L.). Plant Cell Tiss. Organ Cult. 110(2), 275-287.

Takavar, S., Rahnama, H., Rahimian, H., Kazemitabar, K., 2010. Agrobacterium mediated transformation of maize (Zea mays L.). J. Sci. Islam Repub. Iran. 21, 21-29.

Uranbey, S., Sevimay, C.S., Kaya, M.D., Ipek, A., Sancak, C., Başalma, D., Er, C., Ozcan, S., 2005. Influence of different co-cultivation temperatures, periods and media on Agrobacterium tumefaciens-mediated gene transfer. Biol. Plant. 49(1), 53-57.

Vega, C.R.C., Andrade, F.H., Sadras, V.O., 2001. Reproductive partitioning and seed set efficiency in soybean, sunflower and maize. Field Crops Res. 72(3), 163-175.

Weber, S., Friedt, W., Landes, N., Molinier, J., Himber, C., Rousselin, P., Hahne, G., Horn, R., 2003. Improved Agrobacterium-mediated transformation of sunflower (Helianthus annuus L.): assessment of macerating enzymes and sonication. Plant Cell Rep. 21(5), 475-482.

Wu, E., Lenderts, B., Glassman, K., Berezowska-Kaniewska, M., Christensen, H., Asmus, T., Zhen, S., Chu, U., Cho, M.J., Zhao, Z.Y., 2014. Optimized Agrobacteriummediated sorghum transformation protocol and molecular data of transgenic sorghum plants. In Vitro Cell. Develop. Biol. Plant. 50(1), 9-18.

Wu, H., Sparks, C., Amoah, B., Jones, H.D., 2003. Factors influencing successful Agrobacterium-mediated genetic transformation of wheat. Plant Cell Rep. 21(7), 659-668.

Yadav, S.K., Katikala, S., Yellisetty, V., Kannepalle, A., Narayana, J.L., Maddi, V., Mandapaka, M., Shanker, A.K., Bandi, V., Bharadwaja, K.P., 2012. Optimization of Agrobacterium mediated genetic transformation of cotyledonary node explants of Vigna radiata. SpringerPlus. 1(1), 1-8.

Zhang, S., Williams-Carrier, R., Lemaux, P., 2002. Transformation of recalcitrant maize elite inbreds using in vitro shoot meristematic cultures induced from germinated seedlings. Plant Cell Rep. 21(3), 263-270.

Zhong, H., Sun, B., Warkentin, D., Zhang, S., Wu, R., Sticklen, M.B., 1996. The competence of maize shoots meristems for integrative transformation and inherited expression of transgenes. Plant Physiol. 110, 1097-1107.

\section{How to cite this article:}

Sreenu, P., Sateesh Kumar, P., Reddy, M. K., Sailaja, D., Pavan Kumar, G., 2016. Resourceful and high efficiency Agrobacterium mediated transformation of maize (Zea mays L.) using coleoptilar nodal explants. Int. J. Curr. Res. Biosci. Plant Biol. 3(12), 1-9. doi: http://dx.doi.org/10.20546/ijcrbp.2016.312.001 